\title{
Extraction of gold in a centrifugal field of fluid rotation
}

\author{
Svetlana Salomatova ${ }^{1^{*}}$ \\ ${ }^{1}$ The Chersky Mining Institute of the North, Siberian Branch, Russian Academy of Sciences, \\ laboratory “Concentration of Mineral Wealth”,678980, Republic of Sakha (Yakutia), Yakutsk, Lenin \\ str. 43.
}

\begin{abstract}
With the samples of the gold-antimony ore processing products of the Sentachan deposit, flotation experiments were carried out on a laboratory centrifugal flotation machine with peripheral concentrate discharge (CFM) and on a laboratory mechanical flotation machine (FM). The selectivity of falling of mineral particles from the flotation mineralized foam flowing along the inclined plane after flotation under different modes (with and without the use of a collector) was investigated; it was shown that the use of a collector can regulate the intensity and selectivity of the falling of material from the foam layer. It was found that the combination of the effect of the centrifugal force of fluid rotation and the hydrophobic properties of minerals makes it possible to enhance the selectivity of the separation of minerals; during flotation in a centrifugal flotation machine, it is possible to carry out cleaning operations in order to improve the quality of the concentrate.
\end{abstract}

Keywords: concentration, centrifugal flotation, mineral particles, hydrophobic properties, concentrate, extraction

\section{Introduction}

There are some known methods of processing and concentration, which are based on the separation of minerals by specific gravity in water (wet concentration), separation by specific gravity in an ascending air stream (jigging), magnetic permeability (magnetic concentration), surface wetting (flotation), centrifugal action (centrifugation), melting point, etc. [1, 2]. These concentration methods do not allow the extraction of fine and thin gold with a particle size of less than $0.5 \mathrm{~mm}$ to $90 \%$. However, fine and submicron gold is present in all placers, amounting from 30 to $95 \%$ of all gold released from ores [3].

The problem of separating minerals with similar technological properties is solved by increasing the selectivity of separation in concentration processes - using directional reagents, selectively changing the technological properties of minerals using various energy influences [4, 5]; in [6] the methods of concentration and extraction of ultrafine dispersed gold using methods of laser exposure are proposed.

One of the ways to influence the efficiency of the flotation process is the use of additional centrifugal forces of liquid rotation - centrifugal flotation [7].

\footnotetext{
*Corresponding author: salomatova@igds.ysn.ru
} 
During flotation sulphide minerals, as well as rock-forming minerals mainly in the form of slime particles, are usually transferred to concentrate; for the subsequent cleaning of concentrates from waste rock, a combined refinement method is sometimes used, which refers to an additional classification of the material into sand and slurry fractions and to obtaining dump tailings in slime fraction [8]. The reduction in the proportion of sulfide minerals in flotation concentrates in the cleaning cycle is carried out in the mode of depression of some of them. When processing ordinary gold-bearing ores, where the main sulfide minerals are pyrite and arsenopyrite, the process of selective flotation often consists in the separation of just these minerals [9].

In the method of flotation developed in the laboratory "Concentrationof Mineral Wealth" of the Chersky Mining Institute of the North, Siberian Branch of the Russian Academy of Sciences, the separation of mineral particles occurs by hydrophobicity in a thin layer on the surface of the rotating water flow (pulp) [10-13]. The research was carried out using the products of concentration of gold-antimony ore from the Sentachan deposit, characterized by extremely rich ores [14].

Studies of the selectivity of falling of mineral particles from the flotation mineralized foam flowing along an inclined plane after flotation under different modes (with and without the use of a collector) showed that the use of a collector can regulate the intensity and selectivity of material falling from the foam layer. The influence of presence of inhomogeneity of the flow of water under the foam (comparative results of studies with partition walls) on the selectivity of separation of particles is insignificant when using a collector, but it can have a negative effect on the process of separation of minerals in the "starving" mode [10].

\section{Experimental research technique}

Experimental studies were carried out on finely ground ore materials from the Sentachan deposit. Preliminary, a set of studies was carried out to study the material composition of the materials used. For the selection, processing and analysis of samples, the existing methods to identify the granulometric, mineral composition and physical properties of minerals were used.

The use of assay analysis (for gold), chemical (for antimony, arsenic), spectral methods of analysis of the elemental composition on a sequential X-ray fluorescence spectrometer SRS3400 made by Bruker company and an analysis of the phase composition of samples on a D8 DISCOVER X-ray diffractometer with the GADDS system are available for an analysis of the material composition of the separation products.

Characteristics of the applied flotation reagent are as follows: butyl xanthate, the main collector for flotation of sulfide minerals, is used in the form of a $2-10 \%$ solution, at a flow rate of 20-100 g / $\mathrm{t}$ [10].

During the research, an experimental version of a centrifugal flotation machine with peripheral concentrate discharge is used, designed by the Chersky Mining Institute of the North, Siberian Branch, the Russian Academy of Sciences (RF patent) [12]. The technical characteristics of the flotation machine are presented in Table 1. 
Table 1. Technical characteristics of a centrifugal flotation machine with peripheral concentrate discharge.

\begin{tabular}{|l|l|l|}
\hline \multicolumn{1}{|c|}{ Technical specifications } & \multicolumn{1}{c|}{$\begin{array}{c}\text { Unit } \\
\text { Measurements }\end{array}$} & \multicolumn{1}{c|}{$\begin{array}{c}\text { Operating } \\
\text { parameters }\end{array}$} \\
\hline Additional water consumption & $\mathrm{l} / \mathrm{min}$ & $2-3$ \\
Air consumption & $\mathrm{m}^{3} / \mathrm{min}$ & 0.05 \\
Number of body revolutions, $\max$ & $\mathrm{rpm}$ & 400 \\
Electric motor drive power & $\mathrm{kW}$ & under 1.0 \\
Dimensions: & & \\
diameter & $\mathrm{mm}$ & 230 \\
height & $\mathrm{mm}$ & 180 \\
\hline
\end{tabular}

Taking into account the natural flotation activity and high concentration of the studied minerals (pyrite and arsenopyrite) in the samples, two flotation modes were tested - the "starvation" mode and the mode with the addition of potassium xanthate.

It was found that during the flotation variant with the use of a collector, the separation of most of the studied sulfide minerals from the water surface is characterized by reduced dynamics (with the exception of arsenopyrite, all minerals keep their retention capacity in the foam layer), while in a series of flotation experiments in the "starvation" mode, the selectivity of the separation of minerals from the surface water rises significantly. At the same time, the retention capacity of sulfide minerals on the water surface is significantly higher when a collector is used.

\section{Results}

A series of experiments on flotation on a laboratory centrifugal flotation machine with peripheral unloading of concentrate (CFM) and on a laboratory mechanical flotation machine (FM), carried out with the products of concentration of gold-antimony ore, with the same reagent mode, established that the extraction of gold and antimony into concentrate is higher on a centrifugal flotation machine (Fig. 1), and the extraction of arsenic is lower, which makes it possible to obtain a concentrate with an As content of $0.11 \%$.

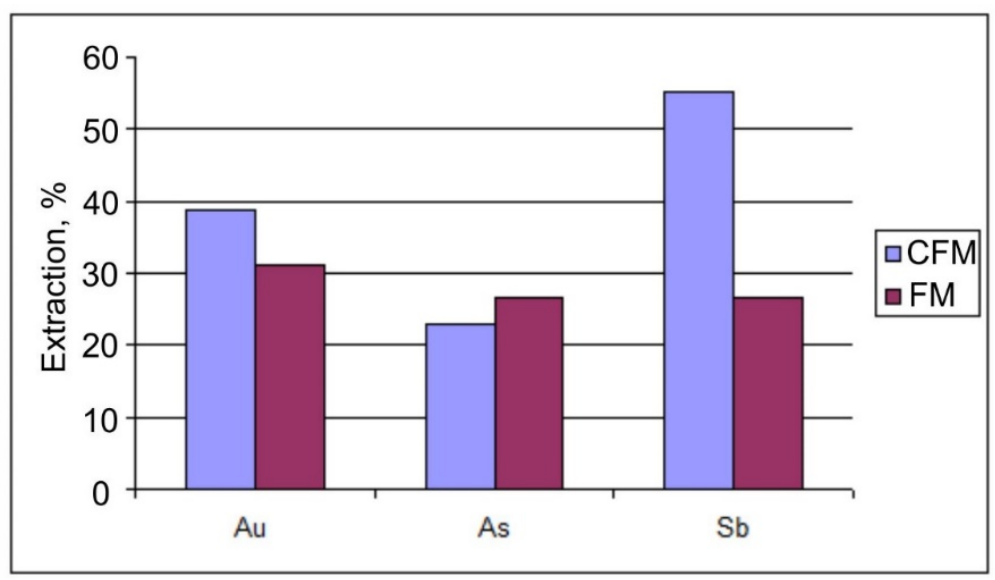

Fig. 1. Extraction of gold, arsenic and antimony in to concentrate during flotation on a centrifugal flotation machine (CFM) and on a laboratory mechanical flotation machine (FM)

Figure 2 shows that, according to the quality of the concentrates, the arsenic content in the concentrate of the centrifugal flotation machine (CFM) is lower than in the concentrate 
in the laboratory mechanical flotation machine (FM), while the antimony content is significantly higher.

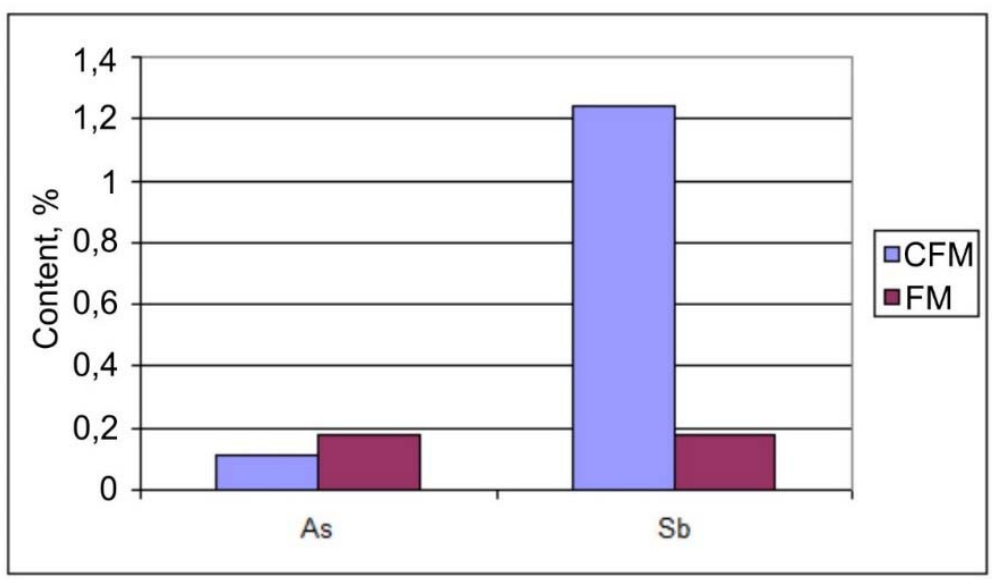

Fig. 2. The content of arsenic and antimony in the concentrates of the flotation by a centrifugal flotation machine (CFM) and a laboratory flotation machine (FM).

Figure 3 shows the diffractogram of the flotation concentrate. The study of the material composition of the flotation products showed that the analyzed samples contain quartz in all samples, and arsenopyrite and antimonite are present in the concentrate.

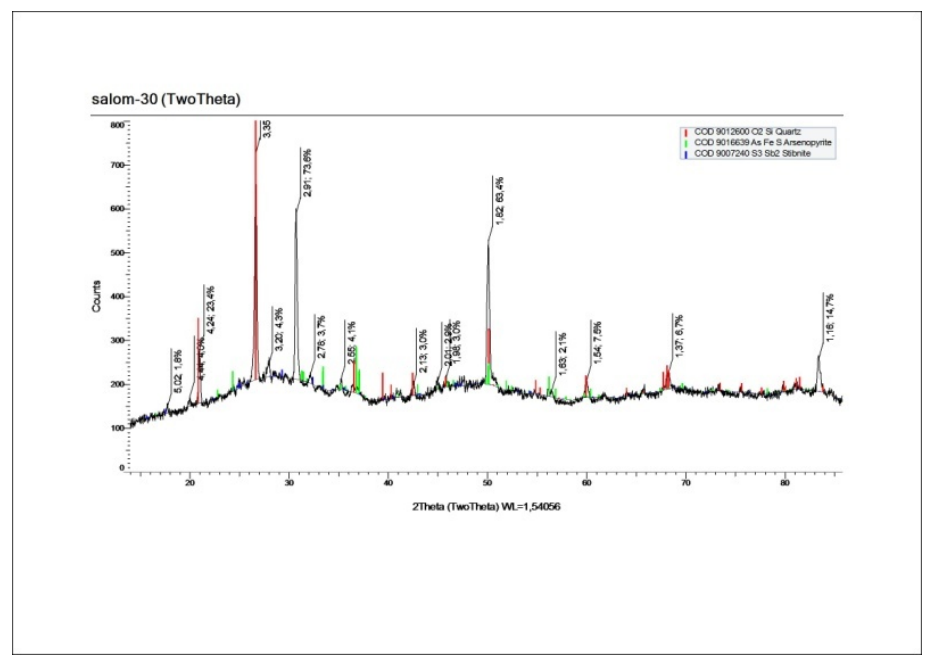

Fig. 3. Diffractogram of flotation concentrate.

\section{Conclusion}

Experimental studies have established that the combination of the effect of the centrifugal force of fluid rotation and the hydrophobic properties of minerals makes it possible to enhance the selectivity of the separation of minerals; during flotation in a centrifugal flotation machine, it is possible to carry out cleaning operations in order to improve the quality of the concentrate. 


\section{References}

1. S.I. Polkin, Concentration of ores and placers of precious metals. (Moscow: Nedra, 1987)

2. V.V. Karmazin, Magnetic, electrical and special methods of mineral processing: In 2 volumes. Vol.1: Magnetic and electrical methods of mineral processing. (Moscow: MSMU, 2005)

3. V.G. Moiseenko, N.S. Ostapenko, A.F. Mironyuk, Miningjournal, 4, 66-68 (2006)

4. V.A. Chanturia, A.A. Lavrinenko, G. D. Krasnov, Miningjournal, 10, 48-52 (2006)

5. A.A. Lavrinenko, G. D. Krasnov, Miningjournal, 2, 108-117 (2007)

6. T.S. Banshchikova, N.A. Leonenko, L.N. Shokina, Processing of ores, 3, 11-14 (2009)

7. Yu.B. Rubinstein, E.Ya. Perelman, I.N. Spivakovsky, Review information. / TsNIITEITyazhmash, - Moscow, - 24 p. No. 1.- (Mining equipment. Series 2) (1988)

8. T.G. Gorbunova, Yu.I. Frolov, Development of the technology for the concentration of ore and placer deposits: Bulletin of academic papers (VNII-1. Magadan, 1985)

9. V.V. Lodeyshchikov, Nonferrous metals, 4, 51-55 (2005)

10. A.I. Matveev, S.I. Salomatova, Flotation of gold on the surface of a rotating fluid; the Russian Academy of Sciences, Siberian branch, the Chersky Mining Institute of the North. (Yakutsk: Publishing house of Yakutia Scientific Center of Siberian Branch of the RAS, 2008)

11. A.I. Matveev, S.I. Salomatova, V.B. Yakovlev, A.M. Monastyrev, N.G. Eremeeva, E.S. Sleptsova, Patent No. 2183998 Russian Federation, 7V03D 1/02 1/24. Method of flotation and centrifugal flotation machine; applicant and patentee isthe Chersky Mining Institute of the North; application filed 25.05.2000; published 27.06.2002, Inventions. Utility Models.- 2002. -No. 18. -Part 2 -P.170 (2002)

12. A.I. Matveev, S.I. Salomatova, A.I. Chikidov, A.M. Monastyrev, V.B. Yakovlev, Patent No. 2248849 RF B 03 D1/24. Method of flotation and centrifugal flotation machine; applicant and patentee is the Chersky Mining Institute of the North; application filed 05.08.2002; published27.03.2005 // Inventions. Utility models.-2005. - No. 9. - Part IV P.949 (2005)

13. S.I. Salomatova, Mining information and analytical bulletin, 11-24, 240-246 (2017)

14. G.I. Boltukhaev, P.M. Solozhenkin, Nonferrous metals, 4, 41-44 (2009) 